Article

\title{
The Tragedy of Maldistribution: Climate, Sustainability, and Equity
}

\section{Elizabeth A. Stanton}

Stockholm Environment Institute, U.S. Center, 11 Curtis Ave., Medford, MA 02144, USA;

E-Mail: liz.stanton@sei-us.org; Tel.: +1-617-627-6872; Fax: +1-617-449-9603

Received: 12 December 2011; in revised form: 2 March 2012 / Accepted: 12 March 2012 /

Published: 16 March 2012

\begin{abstract}
This essay is an initial exploration of the dimensions of the equity/sustainability linkage from the perspective of public goods analysis. Sustainability requires an abundance of public goods. Where these commons lack governance, sustainability is at risk. Equity is a critical component of sustainability that can itself be viewed as a public good, subject to deterioration (maldistribution) when left ungoverned. As is the case for so many forms of environmental degradation, the private benefits of maldistribution tend to overshadow the larger social costs, and the result is a degradation of equity. This article sketches out the analogy of equity as a public good by: examining the evidence regarding current and historical income equality within and between countries; introducing the characteristics of public goods and grounding equity in this idiom; reviewing several theories explaining the sub-optimal provision of environmental goods; applying these theoretical frameworks to the case of equity, with an examination of the potential causes of, and solutions to, maldistribution; and, finally, addressing equity's critical role as a component of sustainability in the case of climate change, with implications for climate policy.
\end{abstract}

Keywords: equity; sustainability; climate change; maldistribution; tragedy of the commons; climate policy; income distribution; climate economics

\section{Equity and Sustainability}

Analysis of public goods has long dwelled within the purview of environmental economics. But the breadth of the commons extends far beyond natural resources and pollution sinks to radio frequencies, the collected works of Shakespeare, and ownership of the moon [1]. Even starting from the more narrow vantage point of environmental amenities, the language and logic of sustainable development 
connects environmental protection with the broader set of public goods related to the advancement of social welfare. The Brundtland Commission's [2] definition of sustainable development as meeting "the needs of the present without compromising the ability of future generations to meet their own needs" explicitly referenced the central role of access to and distribution of resources, noting that "physical sustainability implies a concern for social equity between generations, a concern that must logically be extended to equity within each generation."

Sustainability requires a robust commons (or an abundance of public goods). Where these commons lack governance, sustainability is at risk. Equity is a critical component of sustainability and can, itself - as I argue in this initial exploration — be viewed as a public good, subject to degradation when left ungoverned.

As is the case for so many forms of environmental degradation, the private benefits of maldistribution tend to overshadow the larger social costs, and the result is a degradation of equity. This essay explores the dimensions of the equity/sustainability linkage from the perspective of public goods analysis. The thoughts presented here are best approached as a first exploration of an interesting analogy - equity as a public good - and not as any attempt to form a completely developed theory or model.

The remaining sections of this article sketch out the analogy of equity as a public good. Section 2 examines the evidence regarding current and historical income equality within and between countries, establishing an empirical basis for maldistribution. Section 3 introduces the characteristics of public goods and grounds equity in this idiom. Section 4 reviews several theories in the environmental economics literature regarding how and why the actual quantity of an environmental good might be less than optimal, and, conversely, how an optimal quantity may be achieved. Section 5 applies these theoretical frameworks to the case of equity, examining the potential causes of and solutions to maldistribution. Finally, Section 6 returns to equity's critical role as a component of sustainability in the case of climate change; this section discusses the implications of maldistribution and proffers several related policy conclusions.

\section{Measuring Equity}

Equity can be understood broadly, as a general sense of egalitarianism - the application of the same rules, rights and responsibilities to all individuals in a society — or narrowly, as strict equality of income and wealth. Maldistribution is here defined as failure to achieve potential enlargements of social welfare via a more equal distribution of income or other resources; the determination of "potential enlargements" may include both positive and normative criteria.

The existence of a wide range of collective goods and services suggests that income distribution is a necessary but insufficient metric of equity. Redistribution of income and other resources in the direction of greater equality not only has private costs and benefits to individuals - some must gain and some must lose - but also has some less obvious benefits to the society at large. Greater income equality has been associated with better environmental, health and education outcomes, lower crime rates, and more robust overall social capital [3-9]. Together, these benefits demonstrate the public goods character of equity.

Nonetheless, the distribution of income is by far the best-measured component of equity, an indispensible first cut at the adequacy of resources. The main imperfections of this metric come in three broad categories: the non-monetized, the indivisible, and the ill-measured. 
- Non-monetized aspects of well-being: So much of what we value most in life defies monetization. Income captures neither our family's health nor the health of our local environments $[10,11]$.

- Indivisible household resources: The measurement of distribution is greatly complicated by fundamental ambiguity regarding the basic unit of analysis: household income is not readily divisible into individual income. In a multi-person household, individual earnings do not represent the money available for consumption, which is almost always a function of household income and power dynamics within the household [12,13].

- $\quad$ Ill-measured income data: No dataset exists recording the income of every person (or household) in the world. Indeed, such data exist for very few countries. Instead, income distribution between countries is often estimated from small samples or imputed from data on consumption, while income distribution between countries compares per capita gross domestic product (GDP) (itself, infamous for its omissions and myopic focus on the formal market) across countries [14].

However imperfectly measured, income distribution is one of the most important markers in gauging the scale of global maldistribution. Global income inequality can be decomposed into two elements: between-country inequality (or differences in per capita GDP among all the nations of the world) and within-country inequality (or differences in household income among all of the households of a single nation). The former, when considered in isolation, sometimes incorporates population weights [14]. Both elements are commonly summarized using one or more of the following methods: the percentile ratio, for example, the ratio of the income of the top 10 percent to that of the bottom 10 percent; the Gini coefficient; or the Theil index (See Champernowne and Cowell [15] for a detailed explanation of these measures.).

Recent research from Branko Milanovic, a World Bank economist and the author of a large body of research on current and historical income inequality, reports that global inequality has worsened from 1988 to 2002 (the latest year for which data are broadly available). In 1988, the 10 percent of world population with the highest incomes received 51 percent of global income; in 2002, the top decile received 57 percent [16]. World Bank data have demonstrated that the bulk of this global inequality exists between countries and not within them. Using the Gini coefficient (which ranges from 0, perfect equality, to 100, perfect inequality), global inequality for 1998 was 64, of which 11 points derived from within-country inequality and 53 points from between-country [14]. Over an assortment of measures, Milanovic finds that 71 to 83 percent of global inequality is the result of differences in per capita income among countries.

Bourguignon and Morrisson's [17] construction of global inequality measures for selected years from 1820 to 1992 shows the global Gini rising steadily (if not quite monotonically) over time. Their work also reveals the importance of changes in the regional (and national) composition of world income quantiles. In 1950, Europe and its "offshoots" (defined as "European-populated countries in the Americas and the Pacific) accounted for 81 percent of the top income decile; by 1992, this figure had fallen to 66 percent, while Japan, Korea, and Taiwan climbed from 2 to 18 percent. (For an examination of pre-industrial inequality, see Milanovic et al. [18].)

Within-country Gini coefficients recorded from 2000 to 2009 ranged from 16.8 in Azerbaijan in 2005 to 65.8 in Seychelles in 2007. Countries with the most equal distributions of income cluster in Scandinavia and the former Soviet Republics. The nations with the greatest divergences in income 
include: Angola, Brazil, Colombia, Comoros, Ecuador, Haiti, Micronesia, and South Africa [19]. Many countries in the World Bank dataset have Gini coefficients for either one year, or no Gini data whatsoever; among countries with Ginis for multiple years, some have risen over time while others have fallen (For an additional source of, similarly incomplete, income distribution data see the United Nations University World Institute for Development Economics Research's World Income Inequality Database [20].).

The well-known Kuznets curve maps national Gini coefficients against per capita income. Kuznets identified an inverted U-shaped pattern in this relationship (equality rising and then falling with income) in the United States, United Kingdom and Germany from the late 19th century through 1950 [21]; he later repeated the analysis, finding a similar pattern for a larger set of countries [22,23]. A substantial body of literature rejects the Kuznets hypothesis, finding that the relationship between inequality and growth is both more complex and more idiosyncratic [24-26].

The conclusions drawn from Kuznets' putative pattern have resulted in some troubling policy advice: policy makers need not concern themselves with a decline in equity related to income growth; further growth will bring a more equal income distribution. In the development literature "growth first" policies emphasizing the importance of economic growth over broader investment in sustainable development are thought by some scholars to have resulted in "immiserizing growth," where increased output degrades the terms of trade resulting in a reduction in per capita income [27,28].

Global income inequality between individuals, which includes both the between and within-country components, is large in scale and growing over time. The question of whether 10 percent of global population receiving 57 percent of all income is too much inequality is, of course, a subjective one. The determination of maldistribution is qualitative and is a product, at least in part, of the observer's own place in the income distribution. This led Rawls [29] to ground his theory of justice on an idealized "original position" in which people sit behind a "veil of ignorance" that prevents them from knowing their own situation before choosing distributive principles for society. The remaining sections of this article make the case that a redistribution of income towards greater equality, along with the equalization of access to other key resources, would represent an improvement in social welfare.

\section{Equity as a Public Good}

Pure public goods are defined, in economics, as goods that are non-rival and non-excludable [30,31]. An example may help to clarify: A sandwich is a private good, but a traffic light is a public good. A sandwich is rival (one person's enjoyment of the sandwich clearly impedes others' ability to enjoy that same sandwich) and excludable (it is, in principle, quite feasible for one person to exclude others from eating her sandwich). In contrast, a traffic light is non-rival (many people enjoy the benefits of the traffic light simultaneously without impeding one another's use) and non-excludable (barring some from the traffic light's benefits while still retaining those benefits for oneself would be infeasible). Many public goods exist on the continuum between the purely private and purely public; rivalness in the use of a public park, for example, abounds, and the enclosure of a public space for private use is all too familiar.

The degradation of environmental amenities - clean air and water, the wealth of natural resources, healthy and biodiverse ecosystems — can often be taken as evidence that a good is not purely public, and that private, rival concerns compete for its use. Analysis of the privatization of publicly controlled 
goods has a long tradition in political economy and natural philosophy. Thomas More's Utopia [32] documents the enclosure (or privatization) of English common land for sheep farming. More described the destitution caused by losing access to the commons, writing that rich farmer's "sheep...devour men and unpeople, not only villages, but towns." By the 18th century, the British parliament had adopted legislation enforcing this privatization. Marx [33] wrote of the "expropriation of the agricultural population from the land," and the coincidence of the creation of this landless class with industrialists' need for wage laborers.

Hardin [34] viewed the destruction of environmental "public" goods as inevitable for any finite resource. His well-known "tragedy of the commons"- the argument that in utilizing a common good one reaps the full benefits of one's actions, but only suffers a fraction (1/x, where $x$ is the number of people sharing the commons) of the costs of resource depletion, and that, by ignoring costs felt by others, each individual's net incentive will lead to a destruction of the commons - is a treatise on the need to protect public goods through privatization and state control (It should be noted that the central focus of Hardin's argument is not resource use but population growth. Hardin associates commonly owned property with overuse by arguing that environmental resources are finite but that the potential population, while not infinite, reaches a maximum at a level that would dictate great deprivation in terms of per capita resource use. A commons therefore, he writes, is "too horrifying to contemplate" and "Injustice is preferable to total ruin." Hardin's solution to the perceived problem of over-population was "mutually agreed coercion.").

Ostrom et al. [35] recast Hardin's tragedy as the fate not of all commons, but instead of a particular class of "open-access" commons: "When valuable [public goods] are left to an open-access regime, degradation and potential destruction are the result." Ostrom and her coauthors emphasize the importance of distinguishing between ungoverned, open-access commons, and commons that are governed by a set of effective rules. Governance rules define rights and duties with regard to the public good, and prevent both overuse and insufficient contribution to resource maintenance. Open-access commons are non-excludable but rival and, as such, are indeed tragically vulnerable to depletion.

Boyce [36] points out that in the power to cause a tragedy of the commons, "some are more equal than others... Everyone may have the same right to pollute the air and water, but not everyone has equal means to do so". One's ability to pollute or to extract natural resources is mediated by one's power, broadly defined to include income (or purchasing power), political power, and status. With open-access public goods at least two types of tragedies are possible: overuse, and consequent degradation, by coequal users of the commons; and the appropriation of the commons by more powerful users, transforming it into a private resource. In both cases, the public good is eradicated. Where Hardin saw private property rights as a bulwark between the indefensible commons and its own demise, Boyce and co-authors offer the democratization or communal appropriation of open-access commons as a solution- "establishing the rights of the poor to environmental sinks and raw materials that previously were treated as open-access resources" [37,38].

Like so many of the environmental amenities that underpin sustainability, equity may be viewed as a public good with important social benefits [39]. Equity is an attribute of a group as a whole - any attempt to define it for an individual divests the term of its meaning. Equity is non-rival (many people enjoy the benefits of equity simultaneously without impeding one another's use) and non-excludable (it would be infeasible to bar some from the benefits of equity while retaining those benefits for 
oneself). In light of the preceding review, it seems apparent that equity, as a public good, lacks governance - that is, it shares an important characteristic with open-access commons: private interests can reduce the degree of equity.

While the equity commons cannot be privatized or overused to the point of destruction, per se, it is nonetheless subject to its own particular vulnerability: a tragedy of maldistribution. In this tragedy, one can only increase one's income or other private benefits at the expense of others. And, indeed, in the macroeconomic literature there seems to be little or no positive relationship between growth and inequality [40,41], and a good case has been made in numerous studies for a strong negative relationship [42-45].

Abstracting, for simplicity's sake, from the effects of progressive taxation, the full benefits of a higher-than-average income accrue to individuals who suffer only a fraction $(1 / x$, where $x$ is the number of people in the society) of the social costs of maldistribution (higher crime rates, less social cohesion, etc.). By ignoring costs felt by others, each individual's net incentive drives society towards a depletion of equity.

\section{Sub-Optimal Levels of Environmental Public Goods}

One of the best known economic analyses of natural resource degradation is the Environmental Kuznets Curve (EKC), which has its origins in the Kuznets hypothesis regarding inequality and per capita income discussed above. The EKC literature looks for, and sometimes finds, an inverted-U-shaped relationship between various forms of environmental degradation and per capita income levels, such that pollution levels first rise and then fall with economic growth [46-49]. Evidence for the EKC is mixed, often depending on the choice of pollutant, selection of countries and years, and the range of incomes considered.

The literature critiquing the EKC focuses on the same sort of unfortunate policy implications that are taken from Kuznets' inverted-U shape between inequality and per capita income. The existence of this pattern is not evidence of its inevitability [50]; the eventual reduction in environmental degradation at a given income threshold is better explained as an induced policy response [46]. Like the Kuznets' curve, the EKC has led to what Torras and Boyce term an "incautious policy inference," noting that "as distribution concerns were subordinated to growth by proponents of "trickle-down" economic development, so environmental concerns may be downplayed as a transitional phenomenon that growth will resolve in due course" [51].

EKC analysis builds on a much larger body of literature examining the socio-economic factors affecting environmental quality. A review of the environmental economics literature reveals three main causes for environmental degradation, where the actual quantity of environmental public goods is lower than the optimal quantity: social costs that are external to market transactions; a narrow, and perhaps biased, focus on monetary costs and benefits; and an invisible fist-power relationships that dominate social welfare decisions.

\subsection{Externalities}

In environmental economic theory, optimal quantity of an environmental public good is determined by the intersection of the marginal benefit and marginal cost of that good: 


$$
\frac{d B_{t}}{d Q}=\frac{d C_{t}}{d Q}
$$

where $B_{t}$ is the total benefit, $C_{t}$ is total cost, and $Q$ is the quantity of the environmental good. These marginal benefits and costs include both private benefits and costs, received and spent by consenting agents in a market transaction, and external, or social, benefits and costs. The latter class is often referred to as externalities: impacts of a market transaction on parties not participating in that transaction.

Air pollution is a classic example. The purchase of gasoline (a market transaction between the car driver and the petroleum company) has both private benefits and costs, determining the price of gasoline and quantity sold in the marketplace, and negative externalities. Carbon dioxide emissions, particulates, and other pollutants affect public health in communities where the gasoline is refined and where the car is driven, as well as increasing the atmospheric concentration of greenhouse gases, with far-reaching consequences for global temperatures and weather patterns. These costs are external to the market for gasoline; while their impacts are felt, no one need pay for having caused this damage. The optimal level of gasoline use is determined by the intersection of its marginal total benefits and marginal total costs, but the actual level is set by marginal private benefits $\left(d B_{p} / d Q\right)$ and $\operatorname{costs}\left(d C_{p} / d Q\right)$ :

$$
\frac{\mathrm{dB}_{\mathrm{p}}}{\mathrm{dQ}}=\frac{\mathrm{dC}_{\mathrm{p}}}{\mathrm{dQ}}
$$

When marginal total costs exceed marginal private costs $\left(\mathrm{dC}_{\mathrm{t}} / \mathrm{dQ}>\mathrm{dC}_{\mathrm{p}} / \mathrm{dQ}\right)$, a negative externality exists.

The puzzle of externalities - damages no one need pay for-has long been understood in terms of an absence of governance. Coase [52] explained that where property rights were incomplete-as is the case with many public goods including the atmosphere-costs could be imposed without recourse. Boyce [36] extends this analysis, suggesting that the "winners" from environmental degradation are able to impose costs on the "losers" because the losers may belong to future generations, may be unaware of their losses, or may lack the power necessary to impede the winners' actions. When total costs are greater than private costs the result is too little of an environmental good or too much of an environmental bad.

In applied environmental economics, the cure for a negative externality is to internalize it by placing a price on environmental degradation. Pigou [53] first identified "divergences between marginal social net product and marginal private net product" and suggested a remedy known as the Pigovian tax or "polluter pays principle": simply put, the polluter is made to pay the value of the environmental damage caused. This raises private costs to equal total social costs, such that - given the right price - the market clears at the optimal level. The so-called Coase Theorem [52] states that as long as property rights are well defined (i.e., no open-access or governance problems) and transaction costs are very low, bargaining among the parties causing and affected by the externality will lead to an optimal allocation of the environmental good. (Coase's point was that transaction costs-lawyers, information, negotiation, contracting, and enforcement - are often prohibitively high, impeding an optimal outcome [54]).

Difficulties arise when, as with so many environmental public goods, property rights are incomplete and transaction costs are high for some affected parties. Coase's analysis suggests two complementary 
solutions to sub-optimal levels of environmental goods: (1) clarifying ownership and control of the goods (either by Hardin's privatization or by Boyce's democratization, as discussed in the previous section); and (2) reducing transaction costs (a topic for which an extensive literature exists in development and environmental economics).

\subsection{Cost-Benefit Analysis}

A second cause of a sub-optimal level of environmental public goods is the conflation of utility with income. In modern theoretical welfare economics, individual utility cannot be summed to arrive at a measure of social welfare because it had been deemed impossible to compare the utility experienced by different individuals. The aim of maximizing social welfare was replaced by Pareto improvement - making one person better off without making anyone else worse off — in the first half of the twentieth century. (This avoids a politically controversial conclusion: transferring income from the rich to the poor improves social welfare. The history of thought of these ideas is discussed in Stanton [55].)

Modern applied welfare economics, however, takes a different point of view. Cost-benefit analysis sums up not utility but income to arrive at social welfare, neatly side-stepping diminishing marginal utility and welfare improvement from redistribution. The "compensation test", introduced by Kaldor [56] and Hicks [57], connects cost-benefit analysis to Pareto optimality by introducing the concept of a "potential Pareto improvement", which occurs when the beneficiaries of an action could in principle compensate those harmed and still be better off. They need not actually compensate anyone; merely the potential for such compensation is sufficient to declare the underlying action a benefit to society. (The treatment of income redistribution in theoretical welfare economics is outside of the scope of this article; on this topic see Thurow [39].)

While the compensation test may leave non-economists scratching their heads (by this criteria, anything that increases GDP is a social good!) it is nonetheless a basic tenet in the cost-benefit analysis that has become the litmus test for so much public policy [11]. (For a defense of cost-benefit analysis see the work of Cass Sunstein, including [58-60].) The "optimal" quantity of an environmental good is determined by the intersection of its marginal benefit and marginal cost (as in Equation 2 above), but the benefits of that good are strictly defined in terms of their effect on income. With the interesting exception of a class of optimization models used in climate analysis-discussed below in Section 6-applied economic analysis proceeds as if utility were purely a function of income $(u(y))$ and were neither concave nor convex $\left(u^{\prime \prime}(y)=0\right)$.

Of course, in the broader literature, environmental amenities are widely understood to have non-monetary benefits and costs [61]. But the tightly circumscribed set of values considered in cost-benefit analysis excludes goods that are not easily valued in money terms and means that optimal quantities of environmental goods do not correspond with actual quantities [10]. In analysis of regulations with environmental impacts these omissions often follow a particular pattern: costs are documented completely and accurately, based on engineering models and actual market values, but the benefits of environmental regulation are incomplete, poorly documented, and under-valued. Environmental benefits include lower cancer risks, more abundant wildlife, and the knowledge that a particular ecosystem or natural setting will survive for posterity. Too often the solution to including such priceless amenities in a dollars-and-cents cost-benefit analysis is to acknowledge their importance 
in an aside without assigning them prices-or, effectively, assigning these amenities a price of zero $[62,63]$. This imbalance results in a bias against strong environmental regulations.

Solutions to the deficiencies of cost-benefit analysis include decision-making based on multi-criteria and cost-effectiveness analyses. Multi-criteria analysis combines parallel quantitative assessments using multiple metrics-money, disability-adjusted life years, indices of biodiversity or ecosystem health - with a final qualitative policy decision [64-66]. Cost-effectiveness analysis begins with a threshold taken from a science- or value-based policy decision-this much pollution, and no more - and recommends the most economically efficient means of staying below that threshold [10].

\subsection{Power-Weighted Decision Rule}

Boyce's [9,36] political economy analysis of environmental issues includes the introduction of the "power-weighted decision rule", in which the total impacts of a market activity or environmental regulation are divided up not by separating benefits from costs (the customary division used in analysis of externalities) but instead by separating net winners from net losers. While there may be multiple categories of benefits and costs from a given action, each individual will experience either a negative, zero, or positive net balance of impacts. The optimal quantity of an environmental good is determined by the intersection of net winners' positive marginal net impacts and net losers' negative marginal net impacts.

Unlike the cost-benefit approach, which identifies optimal outcomes in a normative framework, Boyce's model is descriptive, and seeks to explain actual, but sub-optimal, outcomes. Boyce's model is similar to a model of political negotiation elaborated by Bueno de Mesquita [67] in which each actor has an effective "vote" for each potential outcome that is equal to the product of the utility the actor would derive from that outcome, the actor's power, and the salience of the issue to the actor.

Using this new conceptualization of Pigou's classic externality analysis, Boyce explains divergences from the optimal result as the effect of power weights in the objective function for the social decision rule (Equation 3 is a variant of Boyce's objective function in which net benefits, in monetary units, have been replaced by utility):

$$
\mathrm{Z}=\sum_{\mathrm{i}}\left[\pi_{\mathrm{i}} * \mathrm{u}_{\mathrm{i}}(\mathrm{y}, \mathrm{z})\right]
$$

where $Z$ is the decision rule such that the policy is adopted if and only if $Z>0, \pi$ is relative power, and $z$ is a vector of other factors. Each person's contribution to the objective function is weighted by her relative power in society (broadly defined to include purchasing as well as political and social power). When net winners from environmental degradation are more powerful than net losers, the degree of degradation will be higher than optimal (and the quantity of the public good will be lower than optimal); when net losers are more powerful, the degree of degradation will be lower than optimal.

While the latter circumstance is possible (Boyce gives the example of urban "beautification" displacing slum dwellers), there are compelling reasons to expect benefits from environmental degradation to be positively correlated with income and other forms of power. Richer, more powerful people both consume more and control more productive assets, affording them disproportionately large incentives and ability to cause environmental degradation [9,51]. 
If public policy is determined by a power-weighted decision rule, then solutions to sub-optimal quantities of environmental public goods include the redistribution of income and other determinants of power. The more equal the distribution of power between the net winners and net losers, the more closely actual levels of environmental goods will resemble optimal levels.

\section{Strengthening the Equity Commons: Obstacles and Strategies}

The same explanations for sub-optimal levels of environmental public goods can also be applied to maldistribution, or the degradation of the equity commons. The problem of defining an "optimal" level of equity, absent some political analog to the veil of ignorance, is an important concern for a more complete treatment of the practical considerations of basing public policy objectives on equity measurements. In the analogy presented here, however, an "optimal" level of equity can be given a similar treatment to an "optimal" level of environmental quality: debate regarding how to identify an optimum need not impede a general discussion of obstacles to and strategies for moving closer to that optimum.

Redistribution of income in the direction of greater inequality has private benefits and costs - some people grow richer while others grow poorer. But the total marginal benefits and costs that determine the presumed "optimal" level of equity comprise both private and social costs. The negative externalities associated with an erosion of equity include worsening health outcomes, higher crime rates, and a decline in social cohesion. Total marginal costs exceed private marginal costs and, as a result, the actual level of equity is lower than the optimal level.

Cost-benefit analyses of public policies with equity implications consider only the aggregate effects of distributive changes. For a single period, the results of a cost-benefit analysis are neutral to changes in the income distribution: the sum of income does not vary with its distribution. Often, the social impacts of maldistribution do not have monetary values and therefore would not be included in a standard cost-benefit analysis. Because of these limitations, such an analysis would never recommend against a public policy on equity grounds.

The power-weighted decision rule takes a different path to the same conclusion (regarding what will happen, as opposed to what should happen); it acknowledges the presence of winners and losers and assumes that power dynamics determine public policy decisions and the outcome of market activities. The winners from maldistribution are richer and more powerful than the losers, and the result is a lower than optimal level of equity.

As a public good, equity is vulnerable to a similar set of deprivations as many environmental amenities. Taken together, sub-optimal levels of equity may be caused by any and all of the following: social benefits (better health outcomes, greater social cohesion) that are external to market transactions; benefits that are priceless (longer life, better quality of life, more robust natural ecosystems) and therefore difficult to assign a monetary value to; and structures of decision making that weight winners' net benefits and losers' net costs from greater equity with the relative power of those winners and losers, together with an unequal distribution of power in favor of the winners. While the tragedy of maldistribution may be taken to imply the inevitability of sub-optimal equity, there are-just as with solutions for the degradation of environmental public goods - strategies to protect and enhance the equity commons. 
Drawing from the solutions for raising levels of environmental goods towards the optimum, discussed in the previous section, strategies for fortifying and increasing equity may include clarifying property rights, reducing transaction costs, multi-criteria analysis, cost-effectiveness analysis, redistribution of income or wealth, and redistribution of political and social power.

Clarifying property rights: Equity is "owned" collectively, and its social benefits accrue to all. But, just as is the case with many environmental public goods, the lack of a well-articulated, well-respected set of governance rules leaves the rights and responsibilities associated with maintaining an egalitarian society undefined, and leaves the equity commons open to predation [68]. Public recognition of equity as a critical component of social welfare and key element in sustainable development would improve governance and make the benefits that derive from equity more explicit.

Reducing transaction costs: The costs of assuring a "fair" market outcome can be high. In making the point that positive transaction costs, and in particular legal costs and access to the legislature, are important considerations in any market analysis, Coase [54] notes that, "the rights which individuals possess, with their duties and privileges, will be, to a large extent what the law determines. As a result the legal system will have a profound effect on the working of the economic system and may in certain respects be said to control it." Legal defense of the equity commons — and, similarly, the quality of its political representation - is highly circumstantial [69], and each person's or community's access is, regrettably, a function of income.

Multi-criteria analysis: In describing the rationale behind its use of multi-critieria analysis in climate modeling, a United Nations Environment Programme (UNEP) analysis states that, in contrast to cost-benefit analysis, the multi-criteria method "does not impose limits on the forms of criteria or pre-ordain objectives, allowing for consideration of social objectives and other forms of equity rather than focusing only on efficiency" [66]. Where cost-benefit analysis can only see value that is easily expressed in monetary terms, multi-criteria analysis has the potential to measure the broader spectrum of values generated by improved equity, including non-monetary and collective benefits.

Cost-effectiveness analysis: The determination of the most cost-effective approach to a public policy decision related to the equity commons would call for the declaration of a threshold for maldistribution together with analysis identifying the most efficient way to avoid passing that threshold [70]. Criteria establishing an appropriate level of equity would require a normative standard and are therefore underexplored in the social science literature, but there exist numerous criteria setting thresholds for low incomes; a poverty line can be based on positive standards, such as the cost of a subsistence-level basket of market goods [71]. Cost-effectiveness analysis' efficacy in contributing to a more robust equity commons would depend strongly on the chosen income threshold.

Redistribution of income and wealth: Given the definition of equity chosen for this analysis, income redistribution's impact on social welfare is axiomatic. Arrow [72] emphasizes government's critical role in reducing inequality, noting the special case of "fugitive" resources - public goods that resist Hardin's protection by privatization-for which "government intervention may be practically unavoidable." As a purely collective public good, equity resists privatization, but, like other fugitive resources, this quality does not protect it from degradation. Government redistribution of income and wealth can take the form of a progressive system of taxation or of the socialization of private assets concentrated in the hands of the most wealthy. 
A shift in the balance of power-redistribution of political and social power - is central to each of the preceding proposed solutions; each solution corresponds to one of the five dimensions of power outlined by Boyce [36]. Value power is the ability to influence the preferences of others, critical in any effort to reform the public perception of equity. Event power is the ability to determine the set of choices available to others; this power makes it possible to influence our system of jurisprudence, its treatment of equity concerns, and the transactions costs associated with redistribution. Agenda power is the ability to decide what issues will or won't be the subject of public policy, for example, determining the elements included in a multi-criteria analysis. Decision power is the ability to dictate the outcome of a choice involving multiple parties; the power to set an income or inequality target, and to use public policy to assure that it is met, is essential to a cost-effectiveness approach to equity enhancement. Finally, purchasing power is the ability (and willingness) to pay for a particular good or service. The redistribution of income and wealth depends on the balance struck between purchasing power and other forms of political and social power.

Like other public goods, equity, when not well-governed, can easily be degraded. Solutions to the tragedy of maldistribution require a shift in the distribution of power, so that both income and decision-making power are held more equally. The final section of this article examines the role of equity both in the emissions of the greenhouse gases that cause climate change and in climate policy solutions.

\section{Equity for Sustainability: The Case of Climate Change}

The relationship between equity and sustainability is multi-faceted. As the Brundtland Commission suggested, meeting the needs of the present without compromising future generations' ability to meet their own needs requires an equitable distribution of economic and political power. Public goods, both environmental and social, have essential roles to play in maintaining and enhancing sustainability. The direct role of the atmospheric commons may be obvious: current-day greenhouse gas emissions are sustainable only when they do not compromise future generations' standard of living.

But another public good, the equity commons, has two less direct but no less important roles in making climate sustainability possible. First, income levels determine emissions. From 1980 to 2007, the 55 countries with the highest incomes (with 18 percent of 2005 global population) contributed 62 percent of cumulative global emissions, while the 45 countries with the lowest incomes (with 15 percent of 2005 population) contributed 2 percent [73]. Between-country inequality-divergence in GDP per capita-goes a long way towards explaining who will use up how much "emissions space" [74]. (Several researchers have identified an EKC-like curve for carbon dioxide emissions for high-income countries, but not for developing countries $[75,76]$.) The goal of maintaining a good chance of avoiding dangerous climate change imposes a finite global emissions budget [77], implying that emissions allocations are a zero-sum game.

Similarly, within-country inequality reflects the pattern of greenhouse gas emissions across each national population, with richer individuals emitting more than their poorer neighbors [78,79]. Greater income equality both within and between nations - in the absence of new measures to reduce emissions-would increase global emissions, suggesting a trade-off between climate protection and redistributive improvements to social welfare. (This conclusion also requires that the income elasticity of emissions be less than one [80]). 
Second, income levels determine mitigation. Each country's (and each household's) capacity to engage in emissions reductions is a function of its income. Baer et al. [81] find that the 70 percent of global population with the lowest incomes are responsible for only 15 percent of cumulative emissions, and have very little capacity for investing in emissions mitigation. Even so, Baer and co-authors identify viable solutions to the climate crisis that take emissions growth from economic development into account and rely only on the actions of those individuals exceeding a given development threshold. With greater income equality, the responsibility of mitigation could be shared more evenly across the world population.

As with the dubious development and environmental policies that have resulted from Kuznets curve and EKC evidence, it is of paramount importance that historical patterns not be mistaken for destiny. If maldistribution dictates both the cause of and the solution to climate change - the rich made this mess and the rich must clean it up — than what role is left for the rest of humanity?

Boyce [9] provides several reasons to expect that greater equity would result in better (and not, as Ravallion et al. [80] have suggested, worse) environmental outcomes, as predicted by the power-weighted social decision rule: greater income and power are associated with better access to information about environmental outcomes; and technology is subject to social and political influences, which in turn are shaped by the distribution of decision-making power. Income redistribution would lift emissions for the poor by more than it lowers them for the rich — but it could also shift the balance of power in climate policy negotiations, both domestic and international, towards a greater urgency in preventing climate change. It is not obvious which of these effects would dominate and over what time period.

The notion that policies based on equating marginal total costs with marginal total benefits depend strongly on the distribution of income - notably absent in much of environmental economics - has received substantial interest from climate economists. Several well-known integrated assessment models depart from standard applied welfare economics by optimizing utility and not income [55], and the question of income inequality's effect on a worldwide carbon price has been well explored $[82,83]$.

The solutions to the twin tragedies of open-access resources and maldistribution - clarifying property rights, reducing transaction costs, adopting multi-criteria analysis and cost-effectiveness analysis, and redistribution of income, wealth, and political and social power-are also, necessarily, solutions for preventing dangerous climate change:

- Clarifying property rights and reducing transaction costs improve the governance of public goods. For the atmosphere this may mean formalizing its collective ownership and the principle of equal per capita rights to its carbon-storage capacity [84]. For equity, as it relates to climate policy, a concrete representation of "common but differentiated responsibilities" for rich and poor nations in international law would be facilitated by the basic principles set out in several, well known, equity-centered emission allocation proposals [81,85-87].

- Multi-criteria and cost-effectiveness analyses incorporated into integrated climate and economics modeling allow non-monetized, collective public goods, like the atmosphere and equity, to enter into policy recommendations for emission reductions. UNEP's MCA4climate initiative has the explicit goal of using multi-criteria analysis to incorporate non-monetary impacts of climate policies into decision making [66]. Cost-effectiveness analysis of emission reduction 
measures is already common among European researchers, although some of the simplest—but best-known - climate-economics models still engage in cost-benefit analysis [88-90].

- And the redistribution of income, wealth, and political and social power towards greater equality? Evidence assembled by Milanovic and others (cited above) indicates that, at least through 2002, the world income was becoming more, not less, unequally distributed. Boyce's power-weighted social decision rule suggests both that if those most affected by climate damages had more power - whether economic or political — there would be a greater likelihood that emissions would be kept in check, and that the poor will suffer most from climate change. As matters stand today, the rich seem to hold all the cards, possessing the capacity both to emit disproportionate amounts of greenhouse gases and to pay for emissions mitigation measures.

Equity is one of the many public goods on which sustainability depends. In the analysis of the causes of and solutions to climate change, the quality of the equity commons and the governance rules that protect and enhance it are key elements in crafting a viable international agreement on future emissions allocation and burden-sharing of emissions mitigation and climate adaptation costs. More broadly, equity - together with so many of the public goods that provide the foundation for environmental sustainability and sustainable development - is vulnerable. Deliberate policies in favor of increasing equity over time not only improve social welfare, but also act to shore up the foundations for the equity commons of the future, by establishing and strengthening rules for its governance.

\section{References}

1. Barnes, P. Capitalism 3.0: A Guide to Reclaiming the Commons; Berrett-Koehler Publishers: San Francisco; Berkeley, CA, USA, 2006.

2. World Commission on Environment and Development. Our Common Future; Oxford University Press: Oxford, UK, 1987.

3. Kawachi, I.; Kennedy, B.P. Health and social cohesion: Why care about income inequality? BMJ 1997, 314, 1037-1040.

4. Kawachi, I.; Kennedy, B.P. Income inequality and health: Pathways and mechanisms. Health Serv. Res. 1999, 34, 215-227.

5. Wilkinson, R.G.; Pickett, K.E. Income inequality and population health: A review and explanation of the evidence. Soc. Sci. Med. 2006, 62, 1768-1784.

6. Wilkinson, R.G.; Pickett, K.E. The problems of relative deprivation: Why some societies do better than others. Soc. Sci. Med. 2007, 65, 1965-1978.

7. Marmot, M. Social determinants of health inequalities. Lancet 2005, 365, 1099-1104.

8. Gerdtham, U.-G.; Johannesson, M. A note on the effect of unemployment on mortality. J. Health Econ. 2003, 22, 505-518.

9. Boyce, J.K. Inequality as a cause of environmental degradation. Ecol. Econ. 1994, 11, 169-178.

10. Ackerman, F.; Heinzerling, L. Priceless: On Knowing the Price of Everything and the Value of Nothing; The New Press: New York, NY, USA, 2004.

11. Sen, A. The discipline of cost-benefit analysis. J. Leg. Stud. 2000, 29, 931-952.

12. Waring, M. If Women Counted: A New Feminist Economics; HarperCollins: New York, NY, USA, 1990. 
13. Folbre, N. Exploitation comes home: A critique of the Marxian theory of family labour. Camb. J. Econ. 1982, 6, 317-329.

14. Milanovic, B. Worlds apart: Measuring international and global inequality; Princeton University Press: Princeton, NJ, USA, 2005.

15. Champernowne, D.G.; Cowell, F.A. Economic Inequality and Income Distribution; Cambridge University Press: Cambridge, UK, 1999.

16. Milanovic, B. Global Inequality Recalculated: The Effect of New 2005 PPP Estimates on Global Inequality. World Bank Policy Research Working Paper No. 5061, 2009.

17. Bourguignon, F.; Morrisson, C. Inequality among world citizens: 1820-1992. Am. Econ. Rev. 2002, 92, 727-744.

18. Milanovic, B.; Lindert, P.H.; Williamson, J.G. Pre-industrial inequality. Econ. J. 2011, 121, 255-272.

19. World Bank World Development Indicators. Available online: http://data.worldbank.org/datacatalog/world-development-indicators (accessed on 16 June 2011).

20. UNU-WIDER World Income Inequality Database, Version 2.0c; UNU-WIDER: Helsinki, Finland, 2008.

21. Kuznets, S. Economic growth and income inequality. Am. Econ. Rev. 1955, 45, 1-28.

22. Kuznets, S. Quantitative aspects of the economic growth of nations: II. Industrial distribution of national product and labor force. Econ. Dev. Cult. Change 1957, 5, 1-111.

23. Kuznets, S. Quantitative aspects of the economic growth of nations: VIII. Distribution of income by size. Econ. Dev. Cult. Change 1963, 11, 1-80.

24. Taylor, L. Income distribution, trade and growth. In U.S. Trade Policy and Global Growth; ME Sharpe: Armonk, NY, USA, 1996.

25. Randolph, S.M.; Lott, W.F. Can the Kuznets effect be relied on to induce equalizing growth? World Dev. 1993, 21, 829-840.

26. Deininger, K.; Squire, L. New ways of looking at old issues: Inequality and growth. J. Dev. Econ. 1998, 57, 259-287.

27. Bhagwati, J. Immiserizing growth: A geometrical note. Rev. Econ. Stud. 1958, 25, 201-205.

28. Bhagwati, J. Distortions and immiserizing growth: A generalization. Rev. Econ. Stud. 1968, $35,481-485$.

29. Rawls, J. A Theory of Justice; Harvard University Press: Cambridge, MA, USA, 1971.

30. Newman, P. The New Palgrave: A Dictionary of Economics: Four Volume Boxed Set; Newman, P.; Eatwell, J.; Milgate, M., Eds.; 1st ed.; Palgrave Macmillan: London, UK, 1987.

31. Samuelson, P.A. The pure theory of public expenditure. Rev. Econ. Stat. 1954, 36, 387-389.

32. More, T. Utopia; Cassel: London, UK; New York, NY, USA, 1909.

33. Marx, K. Capital: A Critique of Political Economy; International Publishers: New York, NY, USA, 1967; Volume 1.

34. Hardin, G. The tragedy of the commons. Science 1968, 162, 1243-1248.

35. Ostrom, E.; Burger, J.; Field, C.B.; Norgaard, R.B.; Policansky, D. Revisiting the commons: Local lessons, global challenges. Science 1999, 284, 278 -282.

36. Boyce, J.K. Political Economy of the Environment; Edward Elgar: Northampton, MA, USA, 2002. 
37. Boyce, J.K. From Natural Resources to Natural Assets. In Natural Assets: Democratizing Environmental Ownership; Boyce, J.K., Shelley, B.G., Eds.; Island Press: Washington, DC, USA, 2003.

38. Boyce, J.K.; Narain, S.; Stanton, E.A. Reclaiming Nature: Environmental Justice and Ecological Restoration, 1st ed.; Anthem Press: London, UK; New York, NY, USA, 2007.

39. Thurow, L.C. The income distribution as a pure public good. Q. J. Econ. 1971, 85, 327-336.

40. Barro, R.J. Inequality and growth in a panel of countries. J. Econ. Growth 2000, 5, 5-32.

41. Banerjee, A.V.; Duflo, E. Inequality and growth: What can the data say? J. Econ. Growth 2003, 8, 267-299.

42. Persson, T.; Tabellini, G. Is inequality harmful for growth? Am. Econ. Rev. 1994, 84, 600-621.

43. Alesina, A.; Rodrik, D. Distributive politics and economic growth. Q. J. Econ. 1994, 109, 465-490.

44. Woo, J. Why do more polarized countries run more procyclical fiscal policy? Rev. Econ. Stat. 2009, 91, 850-870.

45. Voitchovsky, S. Inequality and economic growth. In The Oxford Handbook of Economic Inequality; Oxford University Press: Oxford, UK, 2009.

46. Grossman, G.M.; Krueger, A.B. Economic growth and the environment. Q. J. Econ. 1995, 110, 353-377.

47. Grossman, G.M.; Krueger, A.B. The inverted-U: What does it mean? Environ. Dev. Econ. 2008, 1, 119-122.

48. Stern, D. The rise and fall of the environmental kuznets curve. World Dev. 2004, 32, 1419-1439.

49. Dasgupta, S.; Laplante, B.; Wang, H.; Wheeler, D. Confronting the environmental kuznets curve. J. Econ. Perspect. 2002, 16, 147-168.

50. Munasinghe, M. Is environmental degradation an inevitable consequence of economic growth: Tunneling through the environmental Kuznets curve. Ecol. Econ. 1999, 29, 89-109.

51. Torras, M.; Boyce, J.K. Income, inequality, and pollution: A reassessment of the environmental Kuznets Curve. Ecol. Econ. 1998, 25, 147-160.

52. Coase, R.H. The problem of social cost. J. Law Econ. 1960, 3, 1-44.

53. Pigou, A.C. The Economics of Welfare; Macmillan and Co. Ltd.: London, UK, 1952.

54. Coase, R.H. The Institutional Structure of Production: Nobel Prize Lecture, 9 December 1991. Available online: http://www.nobelprize.org/nobel_prizes/economics/laureates/1991/coaselecture.html (accessed on 1 December 2011).

55. Stanton, E.A. Negishi welfare weights in integrated assessment models: The mathematics of global inequality. Clim. Change 2010, 107, 417-432.

56. Kaldor, N. Welfare propositions of economics and interpersonal comparisons of utility. Econ. J. 1939, 49, 549-552.

57. Hicks, J.R. The valuation of the social income. Economica 1940, VII, 105-124.

58. Sunstein, C.R. Cost-Benefit Default Principles; Law School, University of Chicago: Chicago, IL, USA, 2000; Volume 99, p. 1651.

59. Sunstein, C.R. The Cost-benefit State: The Future of Regulatory Protection; American Bar Association: Chicago, IL, USA, 2002.

60. Sunstein, C.R. Cost-benefit analysis and the environment. Ethics 2005, 115, 351-385. 
61. Arrow, K.; Solow, R.; Portney, P.R.; Leamer, E.E.; Radner, R.; Schuman, H. Report of the NOAA Panel on Contingent Valuation; 58 Federal Register 4601: Washington, DC, USA, 1993.

62. Ackerman, F.; Stanton, E.A. Testimony on EPA's "Coal Combustion Residuals: Proposed Rule"; Stockholm Environment Institute-U.S. Center: Somerville, MA, USA, 2010.

63. Ackerman, F.; Stanton, E.A. Regulation of Cooling Water Intake Structures at Existing Facilities; Testimony to the U.S. Environmental Protection Agency, Docket ID EPA-HQ-OW-2008-0667, 2011.

64. Stirling, A. Analysis, participation and power: Justification and closure in participatory multi-criteria analysis. Land Use Policy 2006, 23, 95-107.

65. Janssen, R. On the use of multi-criteria analysis in environmental impact assessment in The Netherlands. J. Multi Criteria Decis. Anal. 2001, 10, 101-109.

66. Scrieciu, S. MCA4climate: A Practical Framework for Planning Pro-Development Climate Policies; UNEP: Paris, France, 2011.

67. Bueno de Mesquita, B. Predicting Politics, 1st ed.; Ohio State University Press: Columbus, OH, USA, 2002.

68. Arrow, K.; Bowles, S.; Durlauf, S.N. Meritocracy and Economic Inequality; Princeton University Press: Princeton, NJ, USA, 2000.

69. Friedman, G. "A question of degree": The sanctity of property rights in American history. In Natural Assets: Democratizing Environmental Ownership; Island Press: Washington, DC, USA, 2003.

70. Beckman, S.R.; Formby, J.P.; Smith, W.J. Efficiency, equity and democracy: Experimental evidence on Okun's leaky bucket. Res. Econ. Inequal. 2004, 11, 17-42.

71. Coudouel, A.; Hentschel, J.S.; Wodon, Q.T. Poverty measurement and analysis. In A Sourcebook for Poverty Reduction Strategies; Klugman, J., Ed.; World Bank: Washington, DC, USA, 2002.

72. Arrow, K. Distributed information and the role of the state in the economy. In Inequality Around the World. Palgrave; Palgrave: London, UK, 2002.

73. Stanton, E.A. Development without Carbon: Climate and the Global Economy through the 21st Century; Stockholm Environment Institute-U.S. Center: Somerville, MA, USA, 2011.

74. Stanton, E.A. Greenhouse gases and human well-being: China in a global perspective. In The Economics of Climate Change in China: Towards a Low-Carbon Economy; Fan, G., Stern, N., Edenhofer, O., Xu, S., Eklund, K., Ackerman, F., Li, L., Hallding, K. Eds.; Earthscan: Oxford, UK, 2011.

75. Lindmark, M. Patterns of historical $\mathrm{CO}_{2}$ intensity transitions among high and low-income countries. Explor. Econ. Hist. 2004, 41, 426-447.

76. Galeotti, M.; Lanza, A.; Pauli, F. Reassessing the environmental Kuznets curve for $\mathrm{CO}_{2}$ emissions: A robustness exercise. Ecol. Econ. 2006, 57, 152-163.

77. German Advisory Council on Global Change. The WBGU Budget Approach; German Advisory Council on Global Change: Berlin, Germany, 2009.

78. Ananthapadmanabhan, G.; Srinivas, K.; Gopal, V. Hiding Behind the Poor; Greenpeace India Society: Bangalore, India, 2007.

79. Boyce, J.K.; Riddle, M. Cap and Dividend: A State-by-State Analysis; Political Economy Research Institute: Amherst, MA, USA, 2009. 
80. Ravallion, M.; Heil, M.; Jalan, J. Carbon emissions and income inequality. Oxf. Econ. Papers 2000, 52, 651-669.

81. Baer, P.; Athanasiou, T.; Kartha, S.; Kemp-Benedict, E. The Greenhouse Development Rights Framework: The Right to Development in a Climate Constrained World; Heinrich Böll Foundation, Christian Aid, EcoEquity and Stockholm Environment Institute: Berlin, Germany, 2008.

82. Chichilnisky, G.; Heal, G. Who should abate carbon emissions? An international viewpoint. Econ. Lett. 1994, 44, 443-449.

83. Sheeran, K.A. Who should abate carbon emissions? A note. Environ. Resour. Econ. 2006, 35, 89-98.

84. Narain, S.; Riddle, M. Greenhouse justice: An entitlement framework for managing the global atmospheric commons. In Reclaiming Nature: Environmental Justice and Ecological Restoration; Boyce, J.K., Stanton, E.A., Eds.; Anthem Press: London, UK, 2007; pp. 401-414.

85. Winkler, H.; Jayaraman, T.; Pan, J.; de Oliveira, A.S.; Zhang, Y.; Sant, G.; Miguez, J.D.G.; Letete, T.; Marquard, A.; Raubenheimer, S. Equitable Access to Sustainable Development: Contribution to the Body of Scientific Knowledge; BASIC Expert Group: Beijing, China; Brasilia, Brazil; Cape Town, South Africa; Mumbai, India, 2011.

86. Agarwal, A.; Narain, S. Global Warming in an Unequal World: A Case of Environmental Colonialism; Centre for Science and the Environment: New Delhi, India, 1991.

87. Government of India National Plan on Climate Change; Prime Minister's Council on Climate change: New Delhi, India, 2008.

88. Ackerman, F.; Stanton, E.A. Climate Economics: The State of the Art; Stockholm Environment Institute-U.S. Center: Somerville, MA, USA, 2011.

89. Stanton, E.A.; Ackerman, F. Climate and development economics: Balancing science, politics, and equity. Nat. Resour. Forum 2009, 33, 262-273.

90. Stanton, E.A.; Ackerman, F.; Kartha, S. Inside the integrated assessment models: Four issues in climate economics. Clim. Dev. 2009, 1, 166-184.

(C) 2012 by the authors; licensee MDPI, Basel, Switzerland. This article is an open access article distributed under the terms and conditions of the Creative Commons Attribution license (http://creativecommons.org/licenses/by/3.0/). 